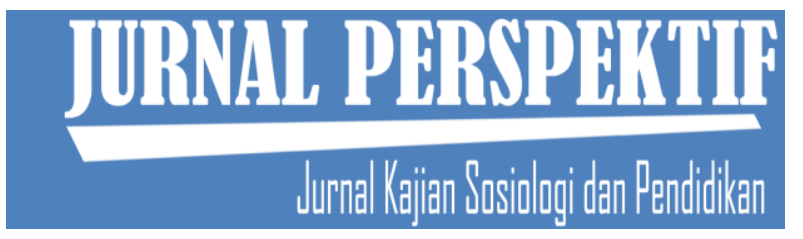

Jurnal Perspektif: Jurnal Kajian Sosiologi dan Pendidikan

Vol. 4 No. 1 Tahun 2021

http://perspektif.ppj.unp.ac.id

Email: perspektif@ppj.unp.ac.id

ISSN: 2622-1748 (Online), 2684-902X (Print)

DOI: $\underline{\text { http://dx.doi.org/10.24036/perspektif.v4i1.406 }}$

\title{
Potret Sosial Komunitas Anak Punk di Kota Perawang, Provinsi Riau
}

\author{
Yani Maisul Fitria ${ }^{1}$, Eka Vidya Putra ${ }^{2}$ \\ ${ }_{1,2}^{1}$ Universitas Negeri Padang \\ Email: yanimaisulfitria@gmail.com, ekavidyaputra@gmail.com
}

\begin{abstract}
Abstrak
Latar belakang penelitian ini bermula dari ketertarikan peneliti ketika melihat banyaknya remaja yang bergabung kedalam komunitas Punk. Penelitian ini bertujuan untuk mengetahui latar belakang sosial munculnya komunitas Punk di Kota Perawang. Teori yang digunakan dalam menganalisis penelitian ini adalah teori pembentukan kelompok yaitu Domisili Theory, Similar Attitude Theory, Activity Interaction Theory dan Practicality Theory. Penelitian ini menggunakan pendekatan penelitian kualitatif tipe studi kasus. Teknik pemilihan informan adalah pusposive sampling. Pengumpulan data dilakukan dengan cara observasi, wawancara dan studi dokumentasi. Hasil penelitian menunjukkan Hasil penelitian menemukan bahwa motivasi anak Punk bergabung ke dalam komunitas Punk disebabkan beberapa alasan-alasan seperti kesamaan hobi, ingin mencari kebebasan, teman sepermainan dan ekspresi diri. Hasil penelitian menemukan bahwa sejarah munculnya komunitas Punk di Kota Perawang dan negara di dunia relatif sama yaitu karena tekanan didalam masyarakat tetapi munculnya komunitas Punk di negara di dunia karena adanya tekanan politik sedangkan munculnya komunitas Punk di Kota Perawang karena adanya tekanan sosial. Maka ditemukan latar belakang sosial munculnya komunitas Punk di Kota Perawang karena menginginkan kebebasan, ekspresi diri, faktor pertemanan dan kesamaan hobi.
\end{abstract}

Kata kunci: Latar Belakang Sosial, Komunitas, Punk

\begin{abstract}
The background of this research stems from the interest of researchers when they saw the number of teenagers who joined the Punk community. This study aims to determine the social background of the emergence of the Punk community in Perawang City. The theory used in analyzing this research is the theory of group formation, namely Domicile Theory, Similar Attitude Theory, Activity Interaction Theory and Practicality Theory. This research uses a qualitative research approach type case study. The technique of selecting informants is purposive sampling. Data collection was carried out by means of observation, interviews and documentation study. The results showed that the results of the study found that the motivation of Punk children to join the Punk community was due to several reasons such as similarities in hobbies, wanting to find freedom, playmates and self-expression. The results of the study found that the history of the emergence of the Punk community in Perawang City and countries in the world is relatively the same, namely due to pressure in society but the emergence of the Punk community in countries in the world due to political pressure, while the emergence of the Punk community in Perawang City is due to social pressure. So the social background of the emergence of the Punk community in Perawang City was found because they wanted freedom, self-expression, friendship factors and shared hobbies.
\end{abstract}

Keywords: Social Background, Community, Punk

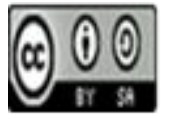

\begin{tabular}{|l|l|l|} 
Received: January 26, 2021 & Revised: February 4, 2021 & Available Online: February 5, 2021 \\
\hline
\end{tabular} 


\section{Pendahuluan}

Punk secara etimologi berasal dari Bahasa Inggris, yaitu "Public United not Kindom" kemudian disingkat menjadi P.U.N.K yang mana dalam bahasa Indonesia berarti sebuah kesatuan/komunitas di luar kerajaan/pemerintah (Setyanto, 2015). Punk merupakan subbudaya yang lahir di London, Inggris. Pada tahun 1970-an, Inggris mengalami krisis ekonomi. Untuk pemulihan ekonomi di Inggris dilakukan dengan cara pembangunan pabrikpabrik sehingga dibutuhkan tenaga kerja yang banyak dalam menghasilkan produk-produk yang diyakini pemerintah nantinya akan dapat memperoleh keuntungan besar dan cepat sehingga bisa memperbaiki dan memulihkan ekonomi negara. Pemulihan ekonomi Inggris berlangsung dengan cepat dan sesuai dengan target yang ditetapkan pemerintah, namun hal ini memiliki dampak secara langsung bagi orang- orang dari kelas pekerja. Gagasaan yang muncul untuk pemulihan ekonomi secepat mungkin membuat pemerintah berpikir dan memandang uang atau keuntungan adalah segala-galanya, sehingga berkembanglah kapitalisme di Inggris. Kapitalisme ini membuat pemerintah mengeksploitasi, menindas dan menekan kelas pekerja untuk memenuhi target pemulihan ekonomi. Akibat adanya kapitalisme ini sehingga menyebabkan terjadinya kesenjangan sosial pada masyarakat Industri sehingga timbul ketidakpuasaan dan perlawanan anak muda kelas pekerja terhadap pemerintah maka lahirlah komunitas Punk pada pertengahan tahun 70-an.

Inti dari Punk adalah semangat anti penyesuaian diri dan bentuk protes atas kondisi lingkungan sosial yang terjadi. Untuk menampilkan karakteristik budaya perlawanan dan kelas menengah, punk menggunakan gaya (musik, fashion, bahasa "pokem", dan lain-lain) (Sugiyati, 2014). Hal ini dapat diamati dari fashion punk seperti sepatu boots, potongan rambut mohawk ala suku indian yang berwarna-warni, celana jeans ketat (skinny), rantai dan paku (spike), baju yang lusuh, badan bertatto, dan memakai tindikan (pearcing) (Rohman, 2009). Musik dari Punk adalah cerminan dari kehidupan masyarakat kelas bawah dengan segala problema yang terjadi pada mereka. Punk merupakan salah satu dari genre musik rock, yaitu salah satu aliran musik yang berirama keras. Lagu-lagu Punk seperti teriakan protes demonstran terhadap kejamnya dunia. Lirik lagu- lagu Punk menceritakan rasa frustrasi, kemarahan, dan kejenuhan berkompromi dengan hukum jalanan, pendidikan rendah, kerja kasar, pengangguran serta represi aparat, pemerintah dan figur penguasa terhadap rakyat (Hasnadi, Bajari, and Wirakusumah, 2012). Punk juga memiliki keberanian menghadapi pemerintah dan penolakan terhadap wewenang yang paling sah. Punk menjadi ruang sosial dan wadah pengungkapan diri bagi kaum muda yang tidak puas serta menjadi sebuah sumber protes dan kritik politik (Hadi, 2018).

Setelah tahun 1977, Punk menyebar dari Eropa ke Amerika bahkan mungkin pada seluruh peradaban dunia Gerakan perlawanan yang dipelopori oleh anak-anak muda yang berasal dari kelas pekerja ini kemudian masuk ke Amerika Serikat yang sedang mengalami masalah krisis ekonomi dan keuangan yang ditandai dengan adanya kemerosotan moral dan etika para-para tokoh elit politik di negara tersebut, sehingga memicu adanya tingkat pengangguran dan kriminalitas yang tinggi. Punk di Amerika Serikat dianggap budaya yang memberikan pengaruh yang sangat kuat. Secara garis besar, kemunculan dan perkembangan Punk di Amerika Serikat dibagi menjadi 3 gelombang. Gelombang pertama yaitu muncul sekitar tahun 1973, dimana ideologi Punk masih dibatasi sekedar perlawanan terhadap musik dominan di AS. Musik Punk Rock dijadikan sebagai perlawanan terhadap musik mainstream seperti pop dan disco. Gelombang kedua muncul pada awal tahun 1980-an, yang mana musik Punk tidak hanya digunakan sebagai media perlawanan terhadap musik mainstream, namun musik Punk sudah mulai mengandung unsur politis didalam lirik lagu yang digunakan oleh 
anak Punk di Amerika Serikat sebagai media perlawanan. Gelombang ketiga muncul pada akhir tahun 1980-an, yang mana pada saat ini sudah terjadi perluasan makna musik dan ideologi Punk. Musik Punk telah dimasuki oleh unsur musik lain seperti pop, sedangkan anak Punk sudah mulai bekerja sama dengan media untuk menyuarakan perlawanannya (Hadi, 2008).

Di Indonesia, musik Punk dikenal sejak akhir tahun 70-an atau awal 80-an, tidak jelas siapa pelopornya tetapi mulai mengalami perkembangan pesat pada tahun 90 -an di Jakarta. Komunitas anak Punk yang terlihat pertama kali di sebuah musik Rock, yaitu konser musik Metalica di stadion Lebak Bulus, Jakarta. Namun komunitas Punk adalah Younger Of Forder (Y.O) sebuah nama yang identik dengan gambaran sekelompok anak muda yang suka bertindak kriminal untuk bertahan hidup di perkotaan. Y.O didirikan oleh sekelompok anak muda dari kelas ekonomi menengah keatas dan masih bersekolah ataupun kuliah di tempattempat elit di Jakarta. Y.O menjadi tempat bagi penggemar musik Punk di Jakarta untuk bertemu dan saling bertukar pikiran dengan menggunakan atribut-atribut Punk sebagai gaya penampilan mereka saat berkumpul.

Di Surabaya, Punk muncul pada tahun 1996. Punk tidak terlepas dari akar sejarahnya sebagai perlawanan individu terhadap situasi politik yang terjadi di sekitarnya. Akibat dari situasi ini, mereka berekspresi melalui musik tertentu yang menyuarakan kegelisahan mereka. Melalui musik mereka mengangkat tema sosial, seks bebas, kecanduan obat, kekerasan dan rasa putus asa yang diwarisi dengan generasi bunga (nama grup musik di tahun 60-an). Bagi mereka musik digunakan sebagai kegiatan komersil sesuai dengan prinsip anti kapitalisme yang dianut, menyuarakan kebebasan, bebas berekspresi, bebas bertingkah dan bebas apa saja sesuai yang diinginkan, sikap hidup yang ingin mereka tunjukkan adalah anti kemapanan (Sugiyati, 2014).

Pada tahun 1990-an, saat media elektronik sangat maju, keberadaan komunitas Punk mulai tercium media dan disoroti secara tajam diseluruh dunia, membuat Punk semakin populer dan kemudian berkembang di Bandung yang notabene adalah kota fashion, banyak remaja mulai berdandan ala Punk dan turun kejalan-jalan untuk mengamen. Punk semakin banyak dari tahun ketahun karena adanya band-band Punk yang sukses seperti Rancid dari California dan Sex Pistols dari Inggris. Keberadaan mereka yang mengglobal membuat Punk menjadi trend diseluruh dunia, bahkan muncul pengimitasian gaya Punk yang akhirnya melahirkan fashion Punk, yaitu mengadaptasi gaya kostum Punk tanpa menganut ideologinya (Setyanto, 2015). Budaya Punk ini telah diterima dan diterapkan dala kehidupan sehari-hari oleh sebagian remaja Indonesia untuk mencari jati diri mereka (Akbar, 2011).

Tidak hanya di kota-kota besar, Punk pun mulai menyebar ke kota-kota sedang dan kecil yang ada di Indonesia, termasuk di Kota Perawang, Provinsi Riau. Kota Perawang merupakan kota industri di pinggir Sungai Siak. Di kota ini terdapat pabrik kertas PT. Indah Kiat yang merupakan anak group Sinar Mas. Secara sosial, struktur masyarakat dapat dikatakan relative tidak ada stratifikasi yang tajam. Setidaknya dapat dilihat dari pola pemukiman, tidak ada pemukiman pemisahan antara perumahan elite, rakyat biasa dan kumuh. Semua masyarakat setara dan hidup secara bersama-sama tanpa melihat seberapa besar penghasilan seseorang. Secara demografis penduduk Kota Perawang merupakan pendatang, sehingga Kota Perawang dapat dikatakan sebagai kota yang multi etnik, artinya secara demografis dan sosiologis Kota Perawang berbeda dengan kota asal lahirnya punk. Melihat dari berbagai latar belakang sosial munculnya komunitas Punk di dunia dan juga Indonesia tentu saja berbeda dengan latar belakang sosial munculnya komunitas Punk di Kota 
Perawang, Provinsi Riau maka menarik untuk melihat bagaimana latar belakang sosial munculnya komunitas Punk di Kota Perawang, Provinsi Riau.

Beberapa penelitian yang relevan dalam penelitian penulis dapat dilihat pada penelitian yang dilakukan oleh Septa Hariadi ( Institut Agama Islam Negeri Bengkulu 2019) dalam skripsinya yang berjudul "Kehidupan Sosial Anak Punk di Kota Bengkulu", hasil penelitiannya sebagai berikut: a). Pada umumnya kehidupan sosial anak Punk di Kota Bengkulu gaya hidup mereka yang cenderung menyimpang seringkali dikaitkan dengan perilaku anarkis, brutal, bikin onar, mabuk-mabukan, narkoba, sex bebas dan bertindak sesuai keinginannya sendiri mengakibatkan pandangan masyarakat bahwa anak Punk adalah anak yang berandal dan tidak mempunyai masa depan yang jelas, b). Masyarakat melabelkan dan menganggap buruk semua bentuk fashion yang tidak sesuai dengan pandangan mereka, masyarakat melabelkan anak Punk sebagai sekumpulan anak berandalan yang menganut gaya hidup yang tidak sesuai dengan lingkungan sekitar sebab kebebasan yang dianut oleh anak Punk telah disalahartikan lewat cara berpakaian maupun tingkah laku mereka ( Hariadi, 2019).

Sedangkan penelitian yang dilakukan oleh Muhammad Ikram ( Institut Agama Islam Negeri Padangsidimpuan 2019) yang berjudul "Fenomena Kehidupan Sosial Komunitas (Anak) Punk di Kota Padangsidimpuan". Hasil penelitiannya menunjukkan bahwa perilaku sosial anak Punk yang ada di Kota Padangsidimpuan pada kenyataannya adalah sekumpulan anak remaja yang berpakaian secara tidak biasa modelnya. Mereka selalu berjalan mengiringi pusat pasar yaitu tempat penjual makanan dan minuman. Mereka mengamen sambil bernyanyi membawa alat musik tradisional yang mereka buat sendiri, kemudian tidak memaksakan kepada pembeli apabila tidak diberi uang kalau sudah selesai bernyanyi. Mereka juga suka membantu orang dalam kesusahan terutama apabila ada yang kena bencana. Mereka akan siap menjadi relawan apabila ada yang membutuhkan mereka. Hubungan mereka dengan masyarakat ada juga manfaatnya bagi pedagang, selain hiburan pelanggan juga bisa menjadi keamanan ruko mereka, karena mereka sering tidur di depan ruko pedagang. Tetapi yang sanat disayangkan adalah dari segi kebersihan dan keagamaan komunitas anak Punk masih kurang ( Ikram, 2019).

Berdasarkan studi relevan diatas persamaan penelitian ini dengan penelitian yang telah dilakukan sebelumnya adalah memiliki objek penelitian yang sama yaitu mengenai komunitas Punk, akan tetapi penelitian tersebut melihat pola perilaku kehidupan anak Punk yang dipersepsikan negatif oleh masyarakat namun sedangkan penelitian yang akan peneliti lakukan adalah latar belakang sosial munculnya komunitas Punk. Maka tujuan penelitian ini adalah untuk menjelaskan bagaimana latar belakang sosial munculnya komunitas anak Punk di Kota Perawang, Provinsi Riau.

\section{Metode Penelitian}

Penelitian ini bersifat deskriptif dengan pendekatan kualitatif tipe studi kasus. Pendekatan kualitatif merupakan penelitian yang bersifat deskriptif. Data yang terkumpul berbentuk kata-kata atau gambar, sehingga tidak menekankan pada angka, serta data yang terkumpul setelah dianalisa selanjutnya dideskripsikan sehingga mudah dipahami oleh orang lain (Sugiyono, 2020). Selain itu, dengan penelitian kualitatif ini penulis dapat memahami apa motivasi anak Punk bergabung kedalam komunitas Punk dan memahami bagaimana aktivitas-aktivias komunitas Punk secara mendalam.

Lokasi penelitian ini dilakukan di salah satu kota kecil di Provinsi Riau yaitu di Kota Perawang. Pemilihan informan memakai teknik purposive sampling dengan jumlah informan 
sebanyak 3 orang anak Punk (Hendri, Yoga dan Agus), tokoh masyarakat dan masyarakat Kota Perawang Teknik pengumpulan data dilakukan dengan cara observasi (pengamatan), wawancara dan studi dokumentasi. Untuk memeriksa keabsahan data dalam penelitian ini maka penulis menggunakan teknik triangulasi data. Teknik analisis data menurut Matthew B. Milles dan A. Michael Huberman yaitu Data Reduction (Reduksi Data), Data Display (Penyajian Data) dan Conclusion Drawing/Verification (Penarikan Kesimpulan).

\section{Hasil dan Pembahasan}

\section{Munculnya komunitas Punk di Kota Perawang}

Berdasarkan hasil penelitian maka ditemukan sejumlah latar belakang sosial munculnya komunitas anak Punk di Kota Perawang diantaranya yaitu:

\section{Ingin mencari kebebasan}

Dalam kamus filsafat, Lorens Bagus mendefenisikan kebebasan sebagai kualitas tidak adanya rintangan nasib, keharusan atau keadaan di dalam keputusan atau tindakan seseorang ( Bagus, 2002). Beberapa remaja menunjukkan keinginan yang kuat untuk jauh dari orang tua dan mereka meninggalkan rumah dengan alasan ingin mencari kebebasan. Banyak remaja yang bergabung kedalam komunitas Punk karena menurut mereka Punk itu bebas sehingga dapat melakukan tindakan yang mereka sukai saja. Akibat kebebasan yang mereka lihat di dalam komunitas Punk tersebut sehingga mereka tertarik dan termotivasi untuk ikut menjadi bagian dalam komunitas Punk tersebut. Keinginan akan kebebasan menjadi salah satu penyebab remaja bergabung ke dalam komunitas sesuai dengan hasil wawancara dengan seorang anak Punk yang bernama Hendri, ia mengatakan:

"...saya awalnya bosan harus dituntut terus oleh orang tua saya harus mendapat ranking di sekolah, hingga akhirnya ada teman saya yang mengajak saya untuk berkumpul dengan komunitas Punk, awalnya saya takut dan tidak tertarik tetapi setelah saya mendekat dan mencoba bergabung saya menjadi nyaman, hal ini yang membuat saya untuk putus sekolah saja dan bergabung kedalam komunitas Punk..." (Wawancara, tanggal 13 November 2020)

Dari apa yang Hendri sampaikan ia mengatakan bahwa dirumah ia merasa dikekang oleh orang tuanya dan ia selalu dituntut oleh orang tuanya tanpa diberi kebebasan. Ia merasa orang tuanya tidak mendukung apa yang diinginkannya sehingga ia mencari sesuatu yang baru di lingkungan sosialnya dan akhirnya ia mengenal komunitas Punk. Ia melihat segeromobolan anak Punk sedang mengamen, terlihat kompak dan sering becanda maka hal itu membuat Hendri tertarik dan termotivasi bergabung ke dalam komunitas Punk karena ia ingin mencari kebebasan akibat selalu dituntut oleh orang tuanya dan merasa tertekan karena tuntutan orang tuanya tersebut.

Hal serupa juga disampaikan oleh salah satu tokoh masyarakat yaitu YP, yang mana ia mengatakan bahwa:

“...Menurut saya salah satu latar belakang sosial munculnya komunitas Punk di Kota Perawang ini karena kan Punk itu merupakan kelompok anak muda yang berpindahpindah dan mencari tempat dimana mereka merasa nyaman. Kemudian mereka menetap di Kota Perawang dan banyak remaja yang penasaran hingga akhirnya mencoba bergabung dan suka dengan kebebasan serta ada masalah dengan keluarga akhirnya mereka memutuskan untuk bergabung ke dalam komunitas itu, karena remaja banyak sekali yang suka dengan kebebasan dan tidak suka dengan aturan...”. (Wawancara, tanggal 30 Desember 2020) 
Berdasarkan yang disampaikan oleh salah satu tokoh masyarakat YP tersebut, maka latar belakang sosial munculnya komunitas Punk di Kota Perawang karena tidak sedikit remaja yang suka kebebasan dan tidak suka diatur, sehingga itu bisa menjadi salah satu alasan kenapa munculnya komunitas Punk di Kota Perawang.

\section{Faktor Pertemanan}

Pertemanan adalah suatu kelompok yang mempunyai hubungan antar individu dengan individu lainnya yang ditandai dengan adanya hubungan emosional, keakraban, saling percaya, sepemikiran, dan saling menerima satu sama lainnya. Seorang remaja yang mempunyai suatu kesamaan baik itu kesamaan nilai, sikap, keyakinan, ideologi, agama dan pengalaman-pengalamannya akan cenderung mempunyai hubungan emosional yang sangat kuat (Rakhmat, 2001). Teman sangat mempengaruhi perilaku serta pandangan hidup dalam mengajak dan mengajarkan perbuatan baik dan buruk bagi seorang remaja. Banyak remaja yang bergabung ke dalam komunitas Punk karena ikut-ikutan teman, seperti yang dikatakan oleh Agus:

“...saya mengenal anak Punk mulai dari masa sekolah SMP karena ada teman saya sudah bergabung kedalam komunitas Punk., pada saat itu saya masih ikut-ikutan bergabung sehingga muncullah kenyamanan bergabung bersama mereka dan setelah tamat SMA saya memutuskan untuk bergabung dengan komunitas Punk tersebut..." (Wawancara, tanggal 17 November 2020)

Hal serupa juga disampaikan oleh salah satu masyarakat yaitu FZ sebagai salah satu pemuda jamaah masjid di masjid aie tabiek, yang mana ia mengatakan bahwa:

“...Banyak remaja yang bergabung kedalam sebuah kelompok karena teman. Apa yang dilakukan oleh temannya maka ia akan ikuti. Seperti halnya dengan komunitas Punk ini, ia bergabung kedalam komunitas itu bisa jadi karena ada salah satu temannya atau bisa jadi karena coba-coba berteman dan akhirnya tertarik kemudian bergabung..." (Wawancara, tanggal 28 Desember 2020)

Berdasarkan hasil wawancara dengan Agus dan FZ tadi maka Kedekatan antara remaja dengan teman-temannya cenderung membuat mereka melakukan apa yang temannya lakukan. Kelompok pertemanan memberikan sebuah dunia tempat remaja dapat melakukan sosialisasi dengan nilai-nilai yang berlaku bukanlah ditetapkan oleh orang dewasa melainkan oleh teman-teman seusianya sesuai dengan apa yang disampaikan oleh Agus ia mengatakan bahwa ia bergabung ke dalam komunitas Punk karena ia ikut-ikutan temannya yang sudah bergabung terlebih dahulu ke dalam komunitas Punk tersebut. Hal ini menunjukkan bahwa teman sangat mempengaruhi perilaku dan sudut pandang kita.

\section{Ekspresi diri}

Hasil penelitian didapatkan bahwa remaja yang menjadi anak Punk disebabkan karena ingin mengekspresikan dirinya. Aturan yang terlalu ketat yang diterapkan oleh orangtua terhadap anak dapat menyebabkan seorang anak bergabung dengan dunia Punk. Seorang remaja yang memiliki semangat muda yang tinggi, serba ingin tahu tentang dunia luar, ingin lebih banyak berekspresi, menginginkan kebebasan, tantangan, membutuhkan pengakuan dan selalu ingin mencoba hal baru yang menurut mereka menarik, namun banyak orang tua yang tidak memberikan kebebasan kepada anak untuk berekspresi dan selalu menuntut anak sesuai dengan keinginannya hingga seorang anak mencoba untuk keluar dari aturan keluarga yang 
merasa mengikat dan membatasi sehingga tidak mempunyai kesempatan untuk mengekspresikan dirinya.

\section{Kesamaan hobi}

Hobi menurut Melia Agustina merupakan sesuatu yang berhubungan dengan gaya gerak yang mendorong kita cenderung dan merasa tertarik pada orang, benda, kegiatan atau pengalaman yang efektif yang dirangsang dari kenyataan itu sendiri (Chasanah, 2017). Banyak remaja yang bergabung kedalam komunitas Punk karena kesamaan hobi seperti hobi dalam bermain musi, hobi dalam membuat tatto, dan hobi dalam membuat karya-karya lainnya. seperti yang dikatakan oleh Yoga:

“...saya bergabung kedalam komunitas Punk karena awalnya saya mencoba ikut serta bergabung dengan komunitas Punk kemudian mereka membuat karya-karya poster dan sablon hal ini yang membuat saya tertarik untuk bergabung dengan komunitas Punk, saya sudah lama sekali ingin pandai membuat poster dan sablon, saya diajarkan dan saya dihargai di komunitas ini..." (Wawancara, tanggal 15 November 2020).

Hal yang sama juga dikatakan oleh Agus:

“...alasan saya bergabung kedalam komunitas Punk juga karena saya suka musik dan saya tertarik dengan musik-musik yang dibawakan oleh komunitas Punk sehingga saya mencoba bergabung dan akhirnya saya betah di dalam komunitas ini..." (Wawancara, tanggal 17 November 2020).

Dari apa yang di sampaikan oleh Yoga dan Agus bahwa mereka bergabung ke dalam komunitas Punk karena tertarik terhadap aktivitas-aktivitas anak Punk yang juga merupakan hobi mereka. Jadi untuk mengembangkan hobi dan minat tersebut mereka bergabung ke dalam komunitas Punk.

Menurut analisis peneliti, latar belakang sosial munculnya komunitas Punk di Kota perawang sebagian besar dikarenakan ingin mencari kebebasan. Sebagaimana pemahaman anak Punk terhadap komunitas Punk yaitu anak Punk di Kota Perawang pada umumnya tidak mengetahui secara rinci bagaimana sejarah kelahiran Punk itu sendiri. Menurut mereka Punk muncul karena tidak adanya keadilan terhadap masyarakat serta karena tidak adanya perhatian pemerintah terhadap masyarakat kelas bawah. Anak Punk di Kota Perawang juga tidak mengetahui apa ideologi Punk itu sendiri. Bagi mereka Punk itu jiwa yang bebas, seperti yang dikatakan oleh Hendri:

“...Punk itu dijiwa kak bukan di pakaian, Punk itu berarti jiwa yang bebas, kami tidak mau bekerja karena kami tidak suka diatur dan kami ingin merasakan kebebasan, ketika kakak sudah merasa bebas dan tidak merasa diatur berarti kakak sudah bisa dikatakan sebagai Punk...”.(Wawancara, tanggal 27 November 2020).

Mereka juga menganggap bahwa Punk itu merupakan jiwa yang mandiri dan tidak menyusahkan orang lain untuk memenuhi kebutuhan sehari-hari mereka sebagaimana yang dikatakan oleh Yoga":

“...Punk itu berarti jiwa yang mandiri, kalau kami pengen sesuatu ya kami harus cari uang dulu, kami harus ngamen dulu dan kalau ada yang mesan karya-karya kami lumayan juga buat kebutuhan kami, jadi kami tidak mengandalkan orang lain untuk diri kami, kami berjuang sendiri dan mencari uang sendiri baik untuk makan dan juga keperluan kami...” (Wawancara, tanggal 27 November 2020). 
Berdasarkan wawancara dengan Yoga, ia menyatakan bahwasanya yang melatarbelakangi kemunculan Punk di Kota Perawang yaitu dengan adanya sekelompok Punk yang berasal dari Kota Medan berkunjung dan menetap selama beberapa bulan di Kota Perawang. Kemudian banyak anak remaja Kota Perawang yang tertarik untuk bergabung kedalam komunitas Punk tersebut.

Anak Punk di Kota Perawang menganggap komunitas Punk ini sebagai wadah untuk bebas bukan sebagai bentuk perlawanan terhadap pemerintah namun mereka terkadang juga mengikuti berbagai bentuk acara yang berupa penolakan terhadap kebijakan pemerintah seperti demo tolak Omnibus Law di pekanbaru pada bulan Oktober 2020, sebagaimana yang dikatakan oleh Agus:

“...Kami menganggap Punk itu sebagai kebebasan, berarti tidak ada yang bisa mengatur kami. Kalau untuk menentang pemerintahan kemana kami mau menentang dan suara kami juga tidak akan didengar nantinya, tetapi ketika ada demo kami juga ikut serta didalamnya..." (Wawancara, tanggal 27 November 2020).

Dari hasil penelitian ditemukan secara keseluruhan anak Punk di Kota perawang tidak mengetahui sejarah kemunculan Punk. Mereka hanya mengetahui sebatas karena ketidakadilan pemerintah terhadap masyarakat kelas bawah. Anak Punk di Kota Perawang menganggap Punk itu sebagai wadah untuk bebas dan tidak diatur oleh siapapun. Hal ini menunjukkan bahwa kemunculan Punk di Kota Perawang berbeda dengan bagaimana munculnya Punk di negara asalnya yaitu Inggris. Komunitas Punk ini tidak mempunyai struktur yang jelas dan tidak memakai sistem kaderisasi dalam kelompoknya, seperti organisasi-organisasi atau komunitas lainnya. Komunitas Punk ini sangat menjunjung tinggi salah satu orang yang merasa dituakan, dihargai dan dihormati oleh para anggotanya. Komunitas Punk ini beranggotakan 9 orang. Akan tetapi, jumlah tersebut bisa melebihi dari 9 orang dikarenakan silih bergantinya serta ada yang datang maupun pergi meninggalkan komunitas tersebut.

Latar belakang sosial munculnya komunitas Punk di Kota Perawang dapat dianalisis menggunakan teori pembentukan kelompok, yaitu Domisili Theory Teori ini menyatakan bahwa seseorang memiliki keinginan untuk bergabung dengan orang lain dengan tujuan untuk menemukan atau menampilkan eksistensi dirinya. Oleh karena itu, pilihan pertama ialah pada mereka yang memiliki kedekatan secara geografis dengan individu tersebut. Kedekatan bisa diartikan sebagai ruang atau daerah (Spatial and geographical proximity). Teori ini berdasarkan asumsi bahwa seseorang akan memilih teman dan pilihan pertamanya ialah orang lain yang secara geografis dekat dengan tempatnya. Misalnya, jika seseorang berada di tempat yang baru atau asing baginya, maka dalam kesendirian orang tersebut berupaya mengenal orang yang berada disekitarnya ( Zulkarnain, 2014). Hal ini sesuai dengan latar belakang munculnya komunitas Punk di Kota Perawang yaitu karena pengaruh teman sepermainan. Mereka bergabung ke dalam komunitas Punk karena ada teman yang sudah bergabung sehingga mereka juga memutuskan untuk bergabung kedalam komunitas tersebut.

Sementara menurut teori Similar Attitude Theory yang merupakan teori kesamaan sikap dari Newcomb (1985) yang memiliki pendekatan bahwa seseorang akan cenderung tertarik dengan orang lain dan bergabung apabila diantara mereka ada kesamaan sikap. Dasar pemikiran konsep ini bermula pada asumsi jika orang berkeinginan untuk belajar, maka dia akan mencari teman yang sama-sama ingin belajar. Aliran ini dianut Feldman yang mengajukan alasan bahwa kesamaan sikap membuat orang merasa terikat satu dengan lainnya dan cenderung terjadi kesamaan sikap, sehingga mereka lebih mudah untuk 
berinteraksi dan menyatukan pendapat (Zulkarnain, 2014). Hal ini sesuai dengan latar belakang sosial munculnya komunitas Punk di Kota Perawang yaitu karena adanya kesamaan hobi dengan kegiatan-kegiatan anak Punk. Mereka tertarik dengan kegiatan-kegiatan komunitas Punk seperti menyablon, membuat poster dan membuat tatto sehingga mereka memutuskan untuk bergabung dengan komunitas Punk.

Selanjutnya menurut teori Activity-Interaction-Sentiment Theory. Teori ini disebut sebagai teori AIS dari Homans dengan konsepsi dasar yang berpijak pada dasar pemikiran sebagi berikut:

a. Semakin banyak seseorang melakukan kegiatan bersama orang lain, maka semakin banyak interaksi yang dapat menumbuhkan rasa kebersamaan.

b. Semakin sering seseorang melakukan interaksi, maka semakin sering orang tersebut membagikan perasaan dengan orang lain.

c. Semakin seseorang memahami perasaan orang lain maka akan semakin tinggi frekuensi interaksi dilakukan, berarti juga semakin sering aktivitas dilakukan (Zulkarnain, 2014).

Hal ini sesuai dengan latar belakang sosial munculnya komunitas Punk di Kota Perawang yaitu yang berawal dari mencoba-coba untuk berkumpul-kumpul dengan komunitas Punk hingga akhirnya tumbuh rasa kebersamaan sehingga memutuskan untuk bergabung kedalam komunitas tersebut. Kemudian menggunakan teori Practicality Theory. Teori alasan praktis atau Practicality Theory ini merupakan teori yang dikembangkan oleh H. Joseph reitz. Teori ini menyatakan bahwa individu berkelompok karena kelompok cenderung memberikan kepuasan atas kebutuhan-kebutuhan sosial yang mendasar dari orang-orang yang berkelompok. Kebutuhan-kebutuhan sosial praktis tersebut dapat berupa alasan ekonomi, status sosial, keamanan, politis, dan alasan sosial lainnya. Contoh seperti seseorang mengelompokdisebabkan karena alasan hobi, senasib, atau alasan-alasan sosial demikian seterusnya. Alasan-alasan praktis ini membuat orang- orang dapat mengelompokkan diri dalam satu group (Azri, 2017). Contoh lain dari teori ini yaitu karyawan-karyawan suatu organisasi mengelompok disebabkan karena alasan ekonomi, keamanan, atau alasan-alasan sosial. Secara logis, karyawan-karyawan yang mendasarkan pertimbangan ekonomi bekerja dalam suatu proyek karena dibayar untuk itu, mereka dapat bersama-sama di dalam seikat buruh karena mempunyai tuntutan yang sama tentang kenaikan upah.Untuk alasan keamanan, bersatunya ke dalam suatu kelompok karena membuat dirinya satu front untuk menghadapi diskriminasi, pemecatan, perlakuan sepihak, dan lain sebagainya (Kamaroellah, 2014). Berdasarkan teori ini remaja bergabung kedalam komunitas Punk disebabkan karena alasanalasan praktis tersebut seperti kesamaan hobi dan minat, menginginkan kebebasan, pengaruh pertemanan dan juga ingin mengekspresikan diri. Alasan-alasan tersebutlah yang membuat remaja mengambil keputusan untuk bergabung kedalam komunitas Punk

Secara keseluruhan sejarah kemunculan komunitas Punk di Kota Perawang, Provinsi Riau dengan sejarah kemunculan komunitas Punk di beberapa negara relatif sama. Kesamaannya yaitu komunitas Punk terbentuk karena adanya tekanan-tekanan di dalam masyarakat seperti di Inggris Lahirnya komunitas Punk karena adanya tekanan dari pemerintah yang mengeksploitasi, menindas dan menekan kelas pekerja sehingga menyebabkan kesenjangan sosial pada masyarakat industri, sedangkan kemunculan komunitas Punk di Kota Perawang juga disebabkan karena adanya tekanan dari masyarakat tetapi tidak tekanan politik melainkan tekanan sosial, seperti tekanan keluarga dan sekolah. Aturan yang terlalu ketat dan tuntutan yang diberikan oleh orang tua terhadap anak seperti harus dituntut menjadi juara kelas, harus pintar dalam bidang pelajaran, harus selalu belajar 
dan tidak punya waktu untuk bermain sehingga menyebabkan anak tidak dapat mengeskpresikan dirinya sehingga ia akan mencari tempat dimana ia merasa nyaman dan membuat ia bergabung kedalam komunitas Punk. Begitu juga dengan seseorang yang tertekan dengan tuntutan sekolah yang mana seseorang dikatakan sukses ketika ia mempunyai pendidikan yang tinggi. Tekanan dan tuntutan inilah yang membuat seorang anak akan mencari tempat dimana ia merasa bebas dari segala tuntutan yang ada. Tekanan-tekanan sosial inilah yang membentuk munculnya komunitas Punk di Kota Perawang, Provinsi Riau.

\section{Kesimpulan}

Berdasarkan hasil penelitian dan pembahasan maka dapat dibuat kesimpulan yang merupakan jawaban atas permasalahan dan tujuan penelitian yaitu sejarah munculnya komunitas Punk di Kota Perawang, Provinsi Riau dengan sejarah munculnya komunitas Punk di negara di dunia relatif sama yaitu sama-sama karena tekanan di dalam masyarakat, tetapi perbedaannya komunitas Punk di negara asal lahirnya komunitas Punk disebabkan karena tekanan politik, sedangkan di Kota Perawang, Provinsi Riau komunitas Punk muncul disebabkan karena tekanan-tekanan sosial seperti tekanan keluarga dan sekolah. Tekanantekanan sosial inilah yang membuat remaja bergabung kedalam komunitas Punk untuk mengekspresikan dirinya.

\section{Daftar Pustaka}

Akbar, J. (2011). Keberadaan Komunitas Punk di Kota Bukittinggi. Padang: Universitas Andalas.

Azri, M. S. P. (2017). Latar Belakang Pembentukan Kelompok Sosial Mahasiswa Pendatang. Jurnal Online Mahasiswa FISIP, 4(2), 5-10.

Bagus, L. (2002). Kamus Filsafat. Jakarta: Gramedia.

Chasanah, R. R. N. (2017). Membangun Kemandirian Melalu Hobi Cosplay Pada Komunitas Albatross-Force di Yogyakarta. Tesis. Universitas Islam Negeri Sultan Kalijaga.

Hadi, B. A. (2019). Perilaku Anak Punk dalam Perspektif Hukum Positif dan Hukum Islama (Studi Kasus di Kabupaten Tulungagung). Skripsi. IAIN Tulungangung

Hariadi, S. (2019). Kehidupan Sosial Punk di Kota Bengkulu. Institut Agama Islam Negeri Bengkulu.

Hasnadi, H., Bajari, A., \& Wirakusumah, T. K. (2012). Komunitas Punk di Kota Bandung dalam Memaknai Gaya Hidup. E-jurnal Mahasiswa Universitas Padjajaran, 1(1), 8.

Ikram, M. (2019). Fenomena Kehidupan Sosial Komunitas Anak Punk di Kota Padangsidimpuan. Skripsi. Institut Agama Islam Negeri Padangsidimpuan.

Kamaroellah, A. (2014). Pengantar Perilaku Organisasi (1 ed.). Jakarta: Pustaka Radja.

Rakhmat, J. (2001). Psikologi Komunikasi. Bandung: PT Remaja Rosdakarya.

Rohman, A., \& Rohman, A. (2009). Fenomena Anak Punk: Sisi Lain Mengenai Ruwetnya Permasalahan Anak Jalanan di Indonesia. Warta Demografi, 39(3), 52-55.

Setyanto, D. W. (2015). Makna dan Ideologi Punk. Desain Komunikasi Visual dan Multimedia, 1(1), 51-58.

Sugiyati, S. (2014). Fenomena Anak Punk dalam Perspektif Teori Michel Foucault, Agama dan Pendidikan. Skripsi. Universitas Islam Negeri Syarif Hidayatullah.

Sugiyono, S. (2020). Metode Penelitian Kualitatif (3 ed.). Bandung: Alfabeta.

Zulkarnain, W. (2014). Dinamika Kelompok Latihan Kepemimpinan Pendidikan. Jakarta: Bumi Aksara. 